S1 Fig. Gene expression profiles of Anemonia viridis and Symbiodinium sp. at low pH.

a

\title{
Anemonia viridis
}

Color Key
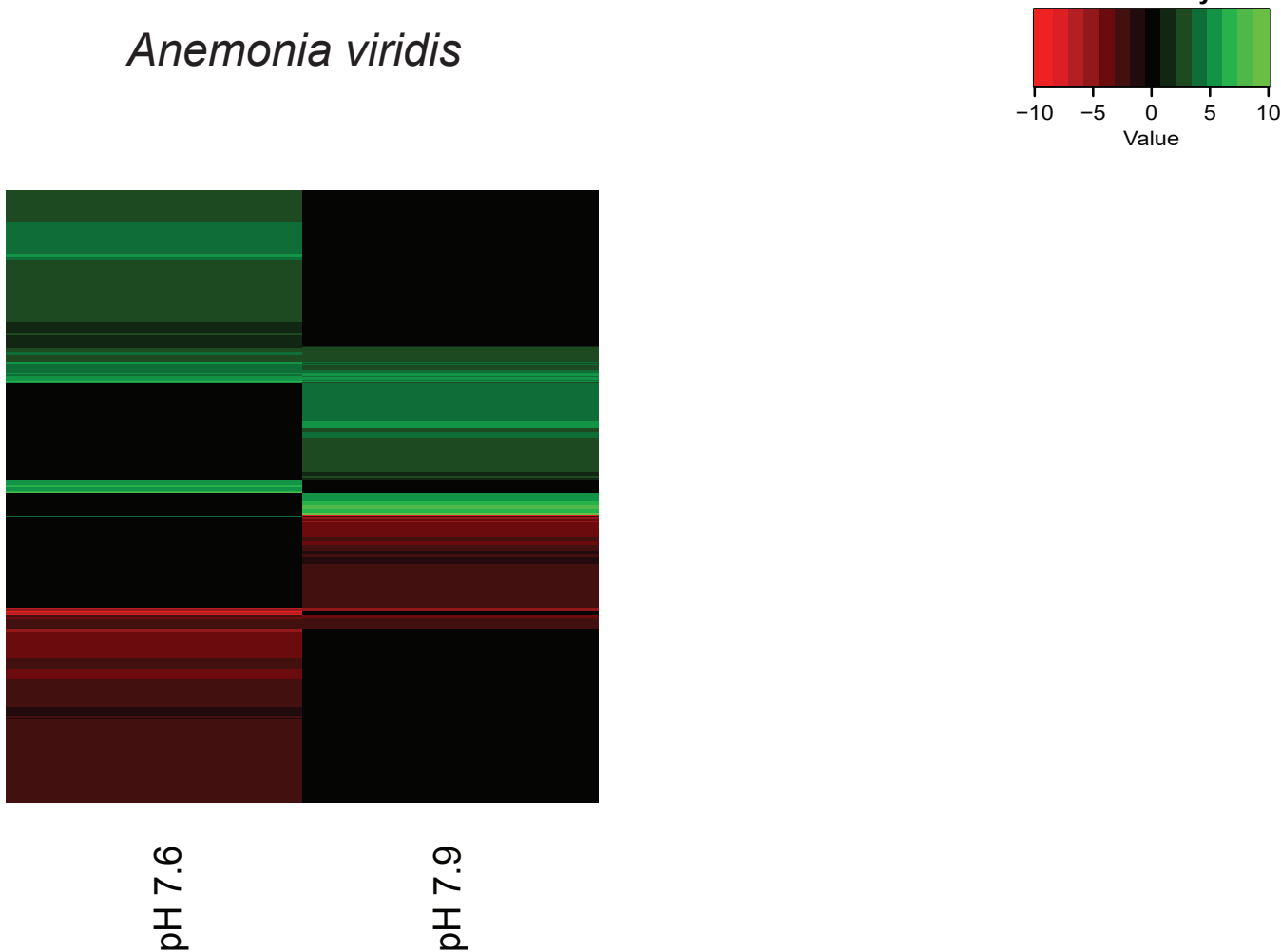

b

Symbiodinium sp.

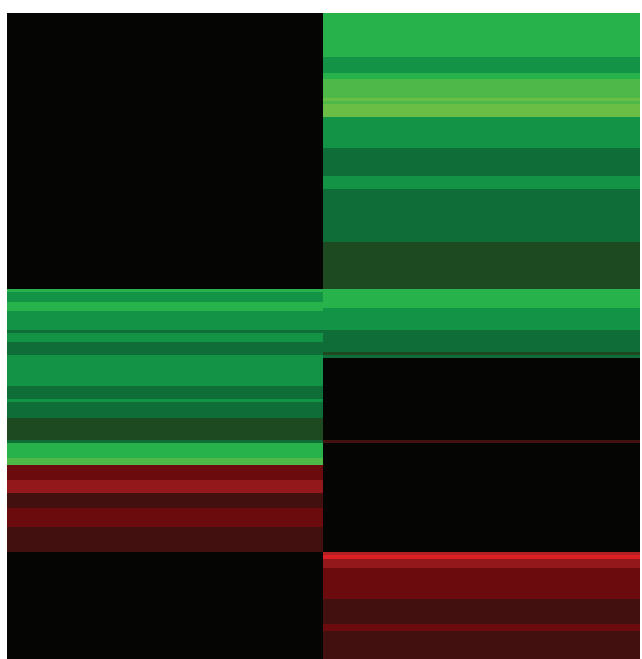

숭
궁

궁
글 